\title{
Rancang Bangun Sistem Jejaring Klaster Berbasis Web Menggunakan Metode Model View Controller
}

\author{
Suprihadi ${ }^{1}$ \\ Rini Kartika Hudiono ${ }^{2}$ \\ Lina Sinatra Wijaya ${ }^{3}$ \\ e-mail : suprihadi@staff.uksw.edu,rinihudiono@gmail.com, \\ linasinatra@yahoo.co.uk.
}

Diterima : 19 Maret 2012 / Disetujui: 19 April 2013

\begin{abstract}
Cluster in Indonesia particularly in the area of Central Java in 2010 totaled 150. Based on the results of the survey in Demak, Wonosobo and Pemalang, most Clusters does not yet have a website as a media product promotion and Cluster communication. Some Cluster already leverages media Blog and facebook but the media still do not meet the expected needs because media Blog and Facebook are not a media for product promotion. This is because the limitations of cost and the scarcity of skilled human resources information technology owned by the Cluster. Therefore, this research was conducted on the design and implementation of a web application that serves as a Networking System Cluster. System development method's using the Prototype Model. Method of MVC (Model View Controller) is used in the implementation of the system, while technology programming using CodeIgniter Framework. As a result, the system is capable of providing the website for each Cluster are listed, so it can be used as a promotional media, publications and communication between Cluster members.
\end{abstract}

Keywords: Cluster, MVC, Framework CodeIgniter

\section{ABSTRACT}

Klaster di Indonesia khususnya di wilayah Jawa Tengah pada tahun 2010 berjumlah 150. Berdasarkan hasil survei di kabupaten Demak, Wonosobo dan Pemalang, sebagian besar

1. Staf Pengajar Fakultas Teknologi Informasi Universitas Kristen Satya Wacana Jl. Diponegoro 52-60, Salatiga 50711, Indonesia

2. Staf Pengajar Fakultas Teknologi Informasi Universitas Kristen Satya Wacana Jl. Diponegoro 52-60, Salatiga 50711, Indonesia

3. Staf Pengajar Fakultas Teknologi Informasi Universitas Kristen Satya Wacana Jl. Diponegoro 52-60, Salatiga 50711, Indonesia 
Klaster belum memiliki website sebagai media promosi produk Klaster dan sarana komunikasi. Sebagian Klaster sudah memanfaatkan media Blog dan facebook tetapi media tersebut masih belum memenuhi kebutuhan yang diharapkan, karena media blog dan facebook memang bukan media untuk promosi produk. Hal ini disebabkan karena keterbatasan biaya dan minimnya sumber daya manusia berkemampuan teknologi informasi yang dimiliki Klaster. Oleh karena itu, pada penelitian ini dilakukan perancangan dan implementasi sebuah aplikasi web yang berfungsi sebagai Sistem Jejaring Klaster. Metode pengembangan sistem menggunakan Prototype Model. Metode MVC (Model View Controller) dipergunakan dalam implementasi sistem, sedangkan teknologi pemrograman menggunakan Framework CodeIgniter. Sebagai hasilnya, sistem ini mampu memberikan website bagi setiap Klaster yang terdaftar, sehingga dapat dipergunakan sebagai media promosi, publikasi dan komunikasi antar anggota Klaster.

\section{Kata Kunci: Klaster, MVC, Framework Codeigniter}

\section{PENDAHULUAN}

Perkembangan teknologi informasi, khususnya teknologi komputer yang kian pesat pada saat ini telah menjadi suatu kebutuhan yang mendasar dalam setiap segi kehidupan manusia maupun masyarakat. Hal ini dapat dilihat dari penggunaan teknologi komputer dalam bidang komunikasi, transportasi, bisnis, bahkan dalam bidang kesehatan. Dalam bidang bisnis, salah satu program pemerintah adalah penguatan kelembagaan klaster, yaitu memberdayakan klaster sebagai pusat bisnis masyarakat guna meningkatkan perekonomian lokal. Sebagai contoh yaitu pada tahun 2007 Bank Indonesia sudah melakukan pengembangan klaster melalui Pilot Project Klaster[1]. SIDaklaster.com adalah website Balitbang Prov. Jawa Tengah berfungsi sebagai media informasi, representasi, konsultasi, fasilitasi dan promosi bagi UMKM berbasis klaster.

Berdasarkan hasil pengamatan bahwa jumlah klaster di Jawa Tengah berjumlah 150, terdiri dari 87 klaster industri, 49 klaster pertanian, dan 14 klaster pariwisata[2]. Berdasarkan hasil survei di Kabupaten Demak, Wonosobo dan Pemalang, beberapa klaster belum sepenuhnya memanfaatkan teknologi informasi dipergunakan dalam proses bisnis atau untuk pengembangan bisnis mereka. Hal ini terbukti bahwa klaster-klaster tersebut belum memiliki situs sebagai sarana sistem informasi maupun sarana promosi produk hasil usaha anggota klaster, melainkan mempergunakan sarana atau media sosial yang ada seperti facebook dan twitter untuk dipergunakan sebagai sarana promosi dan jejaring usaha. Beberapa klaster yang memiliki anggota berkemampuan teknologi informasi, telah memanfaatkan Blog sebagai sarana media promosi bisnis klaster mereka.

Permasalahan-permasalahan tersebut yang mendasari penelitian ini. Salah satu kebutuhan yang mendasar untuk penyelesaian permasalahan tersebut adalah bahwa klaster membutuhkan penerapan teknologi informasi sebagai media promosi, bisnis dan komunikasi bisnis antar anggota klaster, yaitu berupa Website. Berdasarkan hal tersebut, maka penelitian ini bertujuan untuk merancang suatu sistem jejaring klaster yang mampu menyediakan website bagi klaster anggota dengan memanfaatkan satu alamat domain dengan mengimplementasikan menggunakan metode Model View Controller (MVC) dengan teknologi Framework CodeIgniter. Dengan demikian, diharapkan bahwa Klaster dapat memiliki website yg mampu mengelola anggota klaster dan dapat menampilkan produk anggota klaster serta dapat dipergunakan sebagai sarana komunikasi bisnis. Sedangkan manfaat pada bidang akademik yaitu supaya dapat dipergunakan sebagai sarana pembelajaran membangun sebuah aplikasi 
web yang dapat membuat dan menyediakan website dengan memanfaatkan satu alamat domain dengan metode Model View Controller.

Untuk tidak memperluas pembahasan, perlu adanya batasan-batasan untuk menyederhanakan permasalahan, yaitu tidak membahas keamanan konten web, tidak membahas unjuk kerja dari aplikasi yang dibangun, tidak membahas secara detil penerapan teknologi framework CodeIgniter pada proses implementasi aplikasi. Penelitian ini berfokus pada penerapan metode Model View Controller pada proses implementasi sistem dan tidak membahas dampak implementasi sistem bagi Klaster.

\section{KAJIANPUSTAKA}

Penerapan dari arsitektur MVC (Model View Controller) telah banyak digunakan dalam pembuatan aplikasi yang mendukung suatu sistem. Pada penelitian sebelumnya dengan judul Multimedia Pembelajaran Bahasa Inggris Menggunakan Konsep Jejaring Sosial Berbasis Web [3] yang membahas tentang bagaimana membangun sebuah aplikasi web multimedia pembelajaran bahasa inggris dengan menggabungkan konsep e-Learning dan konsep jejaring sosial menggunakan metode MVC dan teknologi Framework CodeIgneter.

Judul kedua pada penelitian selanjutnya adalah "Membangun Website e-Commerce dengan Teknik MVC Menggunakan Framework CodeIgneter"[4] yaitu membuat sebuah cms e-commerce secara mandiri dengan memanfaatkan framework Codeigniter yang sudah menggunakan konsep Model, View, Controller (MVC).

Berdasarkan kedua penelitian terdahulu tersebut maka penelitian ini mendapatkan masukkan tentang penerapan konsep Jejaring Sosial pada sebuah aplikasi web e-Learning, serta penerapan metode MVC pada implementasi suatu sistem berbasis pada web e-Commerce. Sedangkan perbedaan dengan penelitian ini adalah konsep Jejaring Sosial diterapkan pada aplikasi $e$-Commerce, sedangkan metode MVC diterapkan guna memudahkan dalam perawatan dan pengembangan aplikasi karena MVC memisahkan pengembangan aplikasi berdasarkan komponen utama yang membangun sebuah aplikasi seperti manipulasi data, antarmuka pengguna, dan bagian yang menjadi kontrol dalam sebuah aplikasi web.

\section{Sistem Informasi}

Data merupakan sekumpulan keterangan atau bukti mengenai suatu kenyataan yang masih mentah, masih berdiri sendiri-sendiri, belum diorganisasikan, dan belum diolah.

Informasi adalah data yang telah diolah menjadi sebuah bentuk yang berarti bagi penerimanya dan bermanfaat bagi pengambilan keputusan saat ini atau saat mendatang.

Sistem adalah sekumpulan unsur / elemen yang saling berkaitan dan saling mempengaruhi dalam melakukan kegiatan bersama untuk mencapai suatu tujuan.

Sistem informasi adalah sekumpulan komponen pembentuk sistem yang mempunyai keterkaitan antara satu komponen dengan komponen lainnya yang bertujuan menghasilkan suatu informasi dalam suatu bidang tertentu [5]. Hal tersebut berfungsi untuk membantu perencanaan, pengendalian, dan pengambilan keputusan dengan menyediakan rangkuman rutin dan laporan tertentu.

\section{Klaster}

Klaster dapat didefinisikan sebagai grup perusahaan yang berkumpul pada satu lokasi dan bekerja pada sektor yang sama. Dalam hal ini semua yang berhubungan dengan suatu klaster adalah merupakan hubungan yang berfokus pada aktivitas klaster itu sendiri, 
mulai dari pengelolaan produk serta aktivitas lainnya yang mana kesemuanya akan terhubung dalam satu jaringan yang saling terintegrasi, dan data dikelola oleh database sebagai media penyimpanan data terpusat[6].

\section{Sistem Jejaring Sosial}

Sistem jejaring sosial komunitas virtual sebagai perkumpulan sosial yang muncul dari internet ketika cukup banyak orang melakukan diskusi publik yang cukup panjang dan perasaan manusia yang cukup untuk membentuk hubungan personal di dunia maya. Biasanya sekelompok orang ini tinggal di daerah yang terpisah satu sama lain, mereka dapat berasal dari desa atau kota yang berbeda tapi memiliki ketertarikan atau tujuan yang sama untuk dibagikan diantara anggota komunitas [7].

\section{PHP (Hypertext Preprocessor) dan SQL (Structure Query Language)}

Bahasa pemrograman yang digunakan adalah Hypertext Prepocessor (PHP), bahasa pemrograman ini memudahkan dalam membuat aplikasi web dengan cepat, dapat digunakan untuk membuat dynamic website, baik itu yang memerlukan penggunaan database ataupun tidak

Database untuk aplikasi ini menggunakan MySQL karena cukup handal dan gratis. Untuk mengelola database tersebut, aplikasi mengunakan SQL dimana SQL adalah sebuah konsep pengoperasian database, terutama untuk pemilihan atau seleksi dan pemasukan data, yang memungkinkan pengoperasian data dikerjakan dengan mudah secara otomatis[8].

\section{Framework CodeIgniter}

Framework dapat diartikan sebagai kumpulan perintah atau fungsi dasar yang dapat membantu menyelesaikan proses-proses yang kompleks, namun pihak developer tetap harus menulis kode sendiri dan harus menyesuaikan dengan lingkungan framework yang digunakan [9].

Sebuah framework selain menyediakan lingkungan pengembangan sendiri-sendiri juga menyediakan berbagai macam fungsi siap pakai yang dapat digunakan dalam pembuatan situs web. Fungsi tersebut merupakan pengembangan atau penyesuaian fungsi asli PHP agar lebih mudah digunakan atau agar lebih sesuai dengan kebutuhan pengguna.

Tujuan dari framework CodeIgniter ini menurut panduan penggunaan adalah untuk menghasilkan framework yang akan dapat digunakan untuk pengembangan proyek pembuatan situs web dengan cara penggunaan kode program secara manual, dengan menyediakan banyak sekali pustaka yang dibutuhkan dalam pembuatan situs web, dengan antarmuka yang sederhana dan struktur logika untuk mengakses pustaka yang dibutuhkan. CodeIgniter membiarkan developer untuk memfokuskan diri pada pembuatan situs web dengan meminimalkan pembuatan kode untuk berbagai tujuan pembuatan situs web [9]. Beberapa alasan kenapa menggunakan framework CodeIgniter diantaranya yaitu gratis, berjalan di PHP versi 4 dan 5, ringan dan cepat, memiliki arsitektur MVC, dokumentasi dan pustaka yang lengkap.

\section{Model View Controller (MVC)}

Model View Controller atau yang sering disebut dengan MVC merupakan arsitektur yang sangat berguna dalam melakukan pengembangan sebuah sistem. Terdapat 3 komponen dalam pola MVC dan interaksi yang terjadi [10]. 


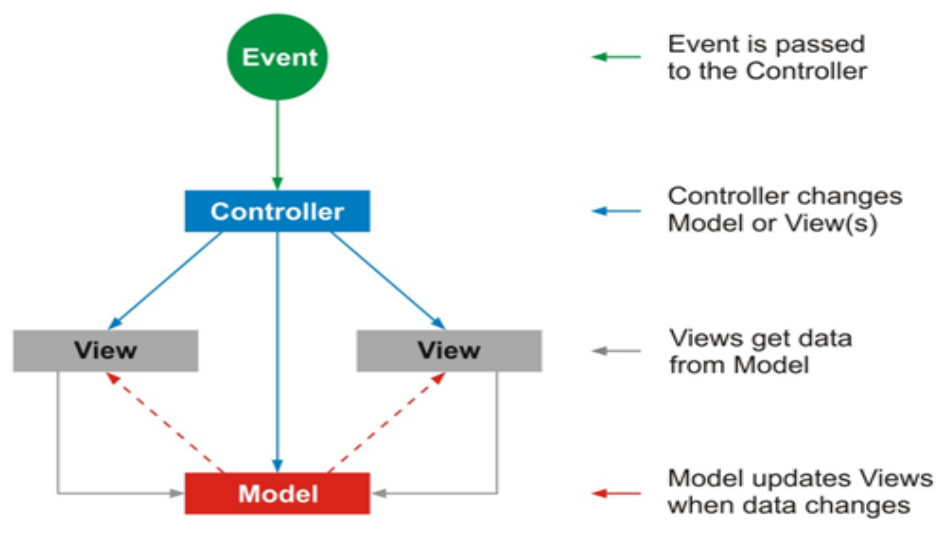

Gambar 1 Arsitektur model, view, controller [10]

Gambar 1 menunjukkan 3 komponen yang terdapat dalam pola MVC (Model, View, Controller) dan interaksi yang terjadi.

\section{PERANCANGAN SISTEM}

Model pengembangan sistem yang dipergunakan pada penelitian ini adalah model prototype. Model prototype merupakan suatu teknik untuk mengumpulkan informasi tertentu mengenai kebutuhan-kebutuhan informasi pengguna secara cepat. Dengan metode prototype ini, pengembang dan pelanggan dapat saling berinteraksi selama proses pembuatan sistem. Secara lengkap, alur model prototype dapat dilihat seperti pada Gambar 2.

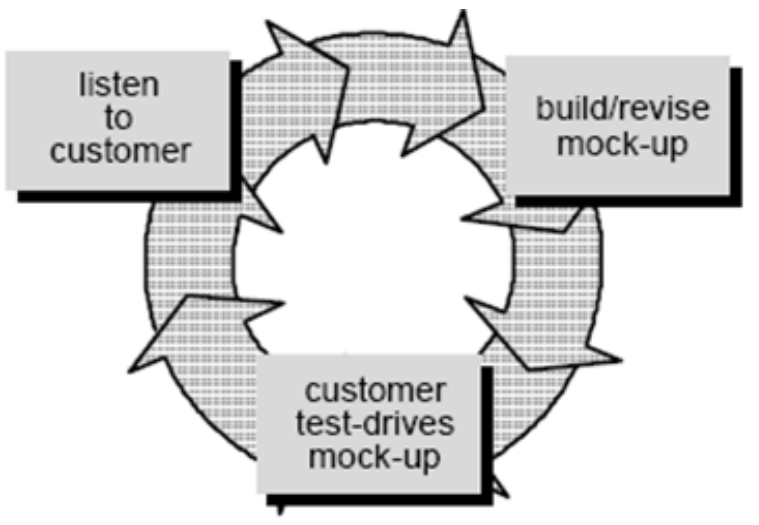

Gambar 2 Prototype Model [11]

Gambar 2 merupakan gambaran tahapan umum dari model prototype. Penjelasan dari tahap - tahap model prototype sebagai berikut:

\section{Listen to Customer}


Pada tahapan pertama listen to customer adalah tahap mengumpulkan informasi tentang kebutuhan aplikasi yang akan dibangun. Pada tahap ini dilakukan wawancara dengan klaster.

Wawancara tentang kebutuhan klaster dilakukan terhadap klaster-klaster di Kabupaten Pemalang, Demak dan Wonosobo Jawa Tengah. Setelah itu dilakukan studi pustaka, menganalisis kebutuhan sistem yang akan dibangun kemudian melakukan rancangan sistem dengan cepat.

\section{Build / Revise Mock-Up}

Tahapan selanjutnya dalam metode prototype yaitu build/revise mock-up. Pada tahap ini dilakukan pembuatan aplikasi secara cepat, yaitu mengimplementasikan hasil rancangan pada tahap sebelumnya menggunakan framework CodeIgniter dan arsitektur MVC. Dengan arsitektur MVC, pengembang dapat lebih fokus pada masing-masing bagian aplikasi, yaitu bagian View untuk implementasi antarmuka sistem, bagian Model untuk implementasi data, dan bagian Controller untuk implementasi pengendalian proses sistem.

Hasil pada tahap ini merupakan aplikasi prototype yang kemudian akan dipergunakan untuk proses tahapan model prototype selanjutnya.

\section{Customer Test-Drives Mock-Up}

Pada tahap ini dilakukan uji dan evaluasi aplikasi prototype oleh user yang bersifat sebagai customer yaitu Klaster. Evaluasi prototype digunakan untuk mendapatkan umpan balik apakah aplikasi sudah sesuai dengan kebutuhan customer. Tahap ini dilakukan kepada Klaster Jawa Tengah di Kabupaten Demak, Pemalang dan Wonosobo. Evaluasi dilakukan dengan cara wawancara dan mengisi kuesioner. Jika hasil uji dan evaluasi prototype belum sesuai dengan kebutuhan customer, maka dilakukan proses perbaikan dimulai kembali ke tahap awal dan dilanjutkan ke tahap berikutnya.

\section{Perancangan Multi Website pada Sistem Jejaring Klaster}

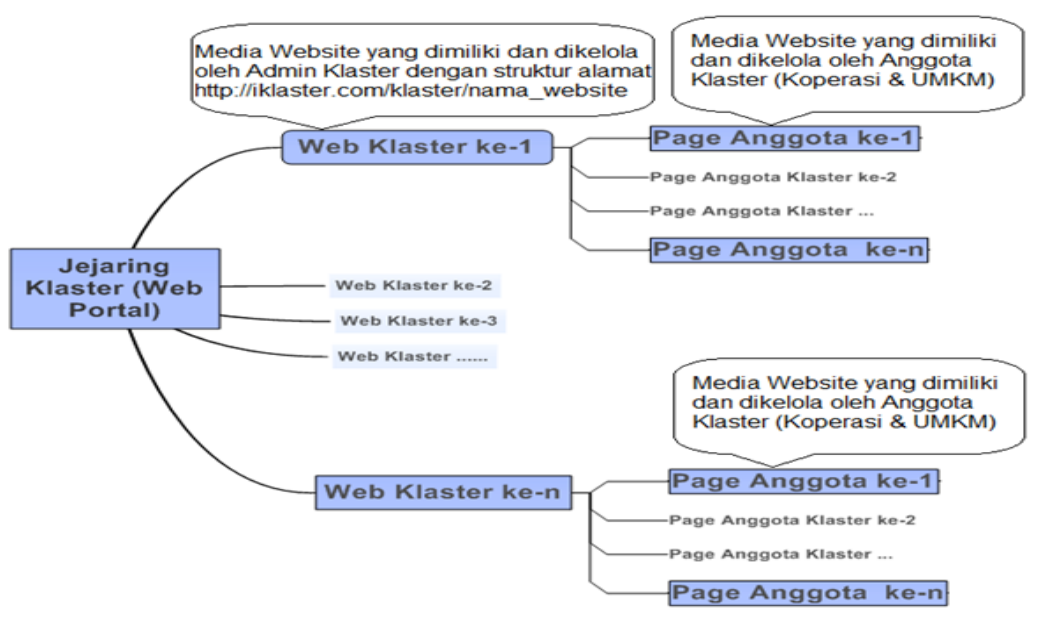

Gambar 3 Mapping Sistem Jejaring Klaster [12] 
Pada Gambar 3 dapat dijelaskan bahwa sistem jejaring klaster mampu menyediakan web klaster atau alamat/situs web klaster berdasarkan klaster yang melakukan registrasi di Sistem Jejaring Klaster dan dapat secara langsung mengakses profil klaster dengan format URL http:domain/klaster/nama_website_klaster. Setelah terdaftar menjadi admin Web klaster, maka klaster dapat membuat halaman anggota sesuai dengan kebutuhan.

\section{Perancangan Konsep Social Network pada Aplikasi e-Commerce}

Hal utama pada suatu aplikasi e-commerce adalah bagaimana cara menampilkan produk supaya pengguna dapat dengan mudah memperoleh informasi produk yang diinginkan. Dalam penelitian ini, dihasilkan desain mapping produk-produk klaster seperti pada Gambar 4. Mapping digolongkan atas kelompok klaster berdasarkan ketentuan yang berlaku di Indonesia.

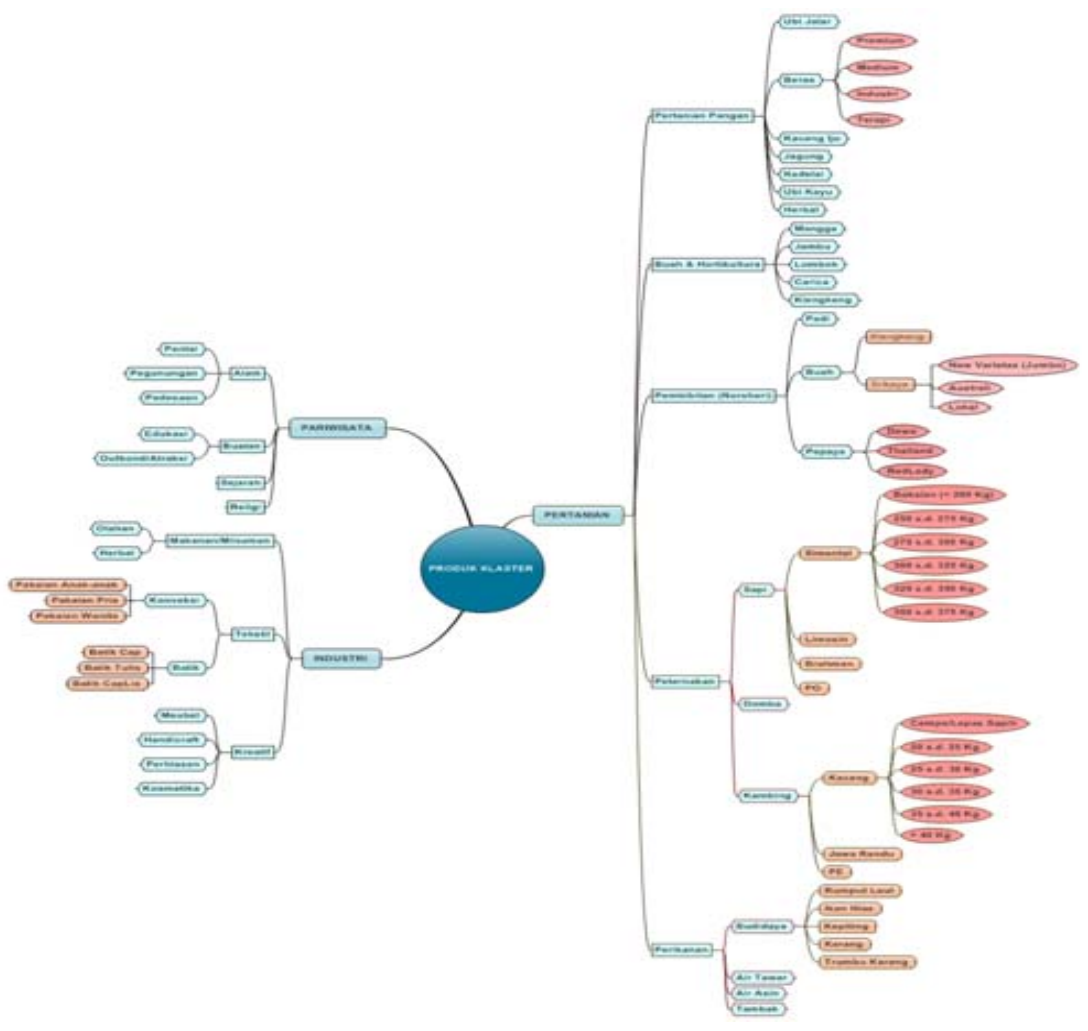

Gambar 4 Mapping Produk Klaster.[12]

Pada Gambar 4 dapat dijelaskan bahwa produk klaster terbagi dalam tiga jenis kelompok, yaitu Pertanian, Pariwisata dan Industri. Kelompok produk klaster memiliki beberapa sub golongan, yaitu Kategori, Jenis dan Klasifikasi. Misal, produk Beras Melati merupakan produk dari klaster kelompok Pertanian, kategori yaitu Pertanian Pangan, jenis yaitu Beras, lalu memiliki 
klasifikasi yaitu Premium. Setelah produk masuk kedalam golongan Klasifikasi, maka produkproduk akan dikonsentrasikan berdasarkan Satuan, kemudian dilakukan proses Sorting Ascending berdasarkan Harga Produk. Setelah produk-produk klaster dikonsentrasikan berdasarkan proses tersebut, maka produk ditampilkan di halaman Homepage portal dalam bentuk image, nama produk dan harga.

Setelah diperoleh desain proses konsentrator produk, maka dilakukan desain atribut produk guna mendapatkan kesamaan pola atribut atau field tabel untuk semua produk klaster. Pada Gambar 5 merupakan mapping atribut produk klaster dan atribut klaster sebagai hasil penelitian.

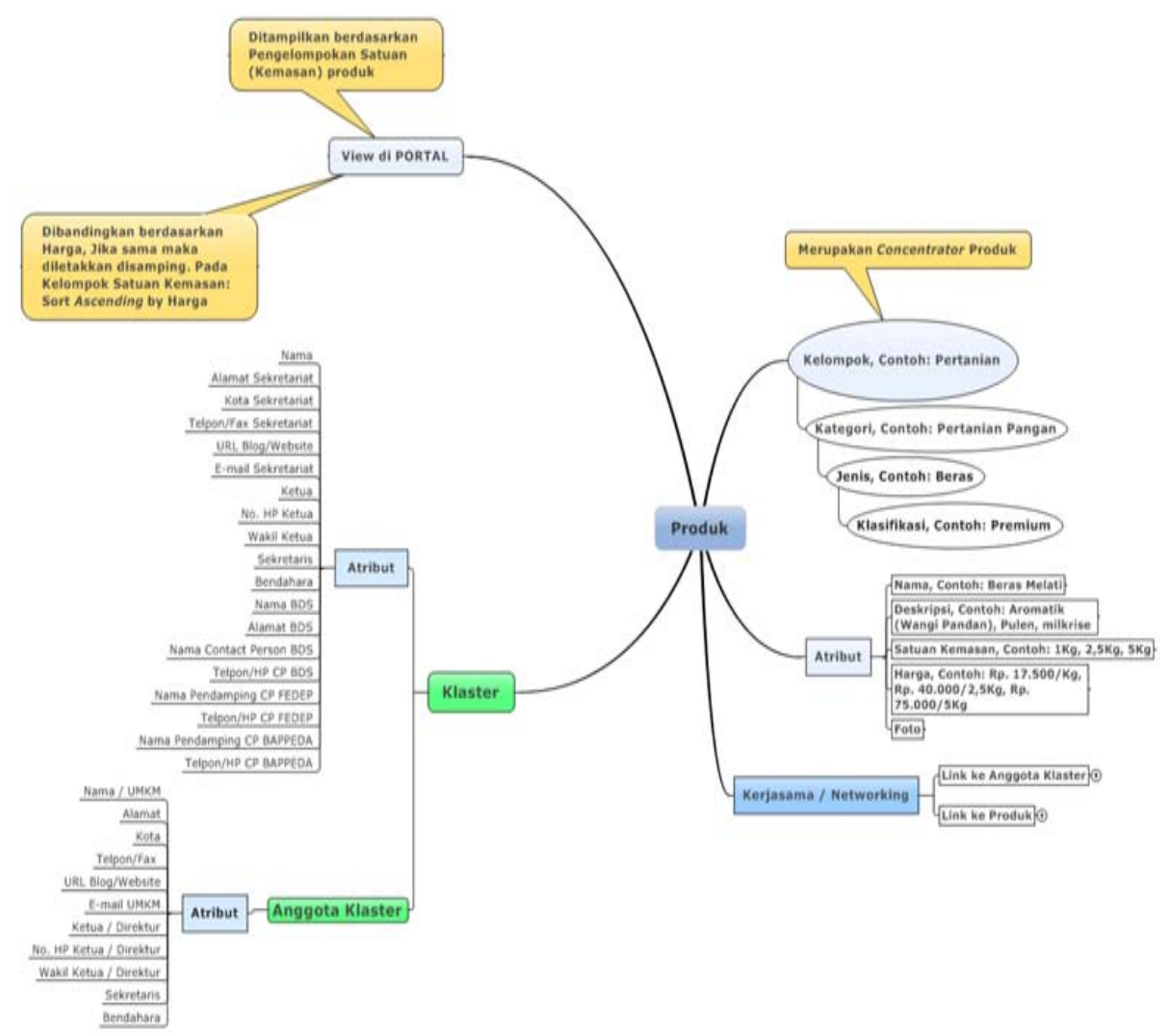

Gambar 5 Mapping Atribut Klaster [12]

Pada Gambar 5 dijelaskan bahwa setiap produk klaster memiliki atribut yaitu kelompok, kategori, jenis, klasifikasi, nama produk, deksripsi, satuan, harga dan foto. Sedangkan klaster memiliki atribut seperti yang terlihat pada Gambar 5. Untuk jejaring produk dibutuhkan tabel 
berbeda yaitu tabel kerjasama atau networking/jejaring dengan atribut yaitu nama produk, jejaring ke nama produk, jejaring ke anggota klaster.

\section{Diagram Alir Proses Pembuatan Website Klaster}

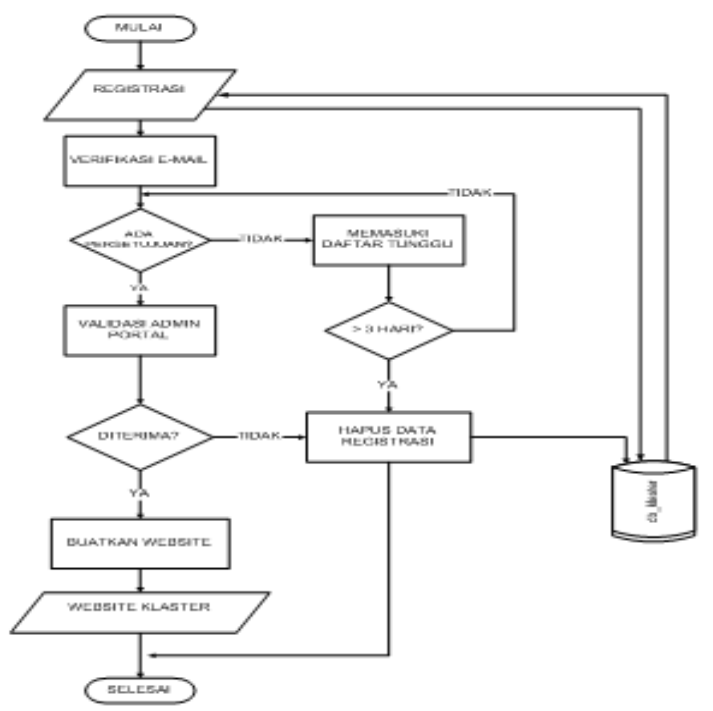

Gambar 6 Diagram Alir Proses Registrasi Klaster[12]

Pada Gambar 6 terlihat bahwa proses registrasi diawali dari seorang seorang pengurus klaster melakukan registrasi dengan cara mengisi form registrasi. Setelah mengisi data registrasi, maka pengurus klaster akan menerima verifikasi $e$-mail. Proses verifikasi berfungsi juga sebagai anti spam dari sistem jejaring. Pengurus klaster harus menerima verifikasi $e$-mail supaya data klaster dapat tersimpan pada database sistem. Jika pengurus klaster tidak melaksanakan verikasi e-mail dalam kurun waktu 3 (tiga) hari, maka secara otomatis data registrasi klaster akan dihapus.

Setelah melaksanakan verifikasi e-mail maka data klaster akan masuk kedalam daftar tunggu validasi admin portal. Jika klaster mendapat validasi admin portal berupa ditolak maka data klaster dihapus. Jika mendapat validasi diterima oleh admin portal, maka klaster akan mendapatkan website klaster. Setelah mendapat website maka pengurus klaster tersebut secara otomatis telah terdaftar sebagai admin klaster. Sebagai admin klaster diijinkan untuk login dan dapat mendaftarkan para anggota klaster untuk dapat mengakses website klaster. Anggota klaster dapat mempergunakan website klaster untuk upload produk serta melakukan jejaring bisnis dengan klaster lain atau sesama anggota klaster.

\section{Perancangan Aplikasi}

Perancangan aplikasi web sistem jejaring klaster ini dirancang menggunakan UML (Unified Modeling Language) sebagai pemodelan sistem. 


\section{Use Case Diagram}

Sebuah use case merepresentasikan keseluruhan kerja sistem secara garis besar dan juga merepresentasikan interaksi antara aktor-aktor dengan sistem yang dibangun serta menggambarkan fungsionalitas yang dapat diberikan sistem kepada user. Beberapa aktor adalah entitas manusia atau mesin yang berinteraksi dengan sistem untuk melakukan pekerjaanpekerjaan tertentu. Use case diagram sistem yang akan dibangun dapat dilihat pada Gambar $7[12]$.

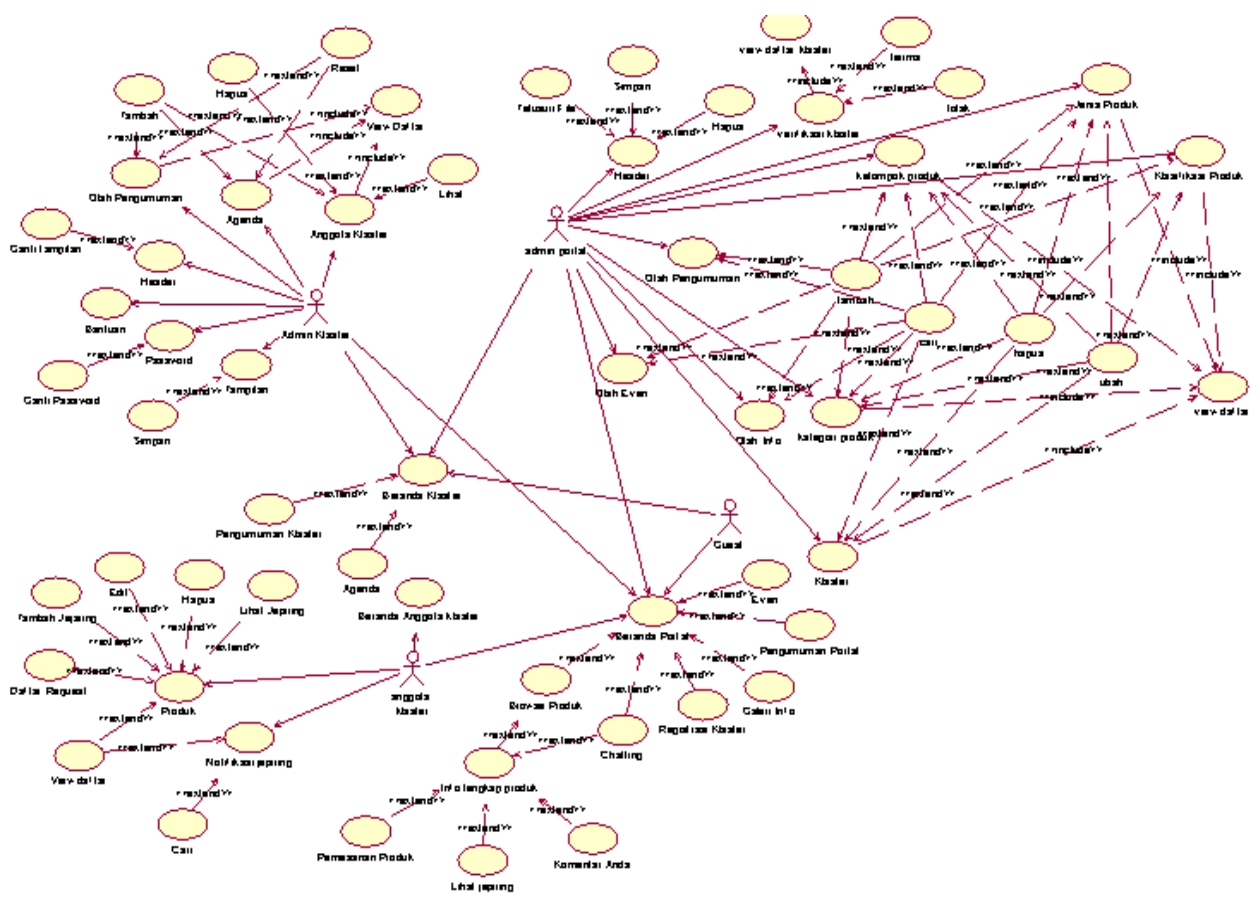

Gambar 7. Usecase Diagram

Gambar 7 menjelaskan bahwa admin portal memiliki hak akses secara penuh. Diantaranya adalah mengelola master data produk ( kelompok produk, kategori produk, jenis produk, dan klasifikasi produk), manage profil klaster dan anggota klaster, manage info, manage pengumuman, manage even, manage header. Admin klaster di sini memiliki hak akses untuk manage anggota klaster, manage agenda, manage pengumuman dan manage pengaturan (tampilan, header, password). Anggota klaster yang memiliki hak akses untuk manage hasil produk (tambah produk, daftar request, tambah jejaring, lihat jejaring, edit produk, hapus produk). Guest yang memiliki hak akses hanya untuk input pemesanan, input komentar dan view info lengkap (lihat jejaring, lihat agenda klaster, lihat pengumuman klaster). 


\section{Activity Diagram}

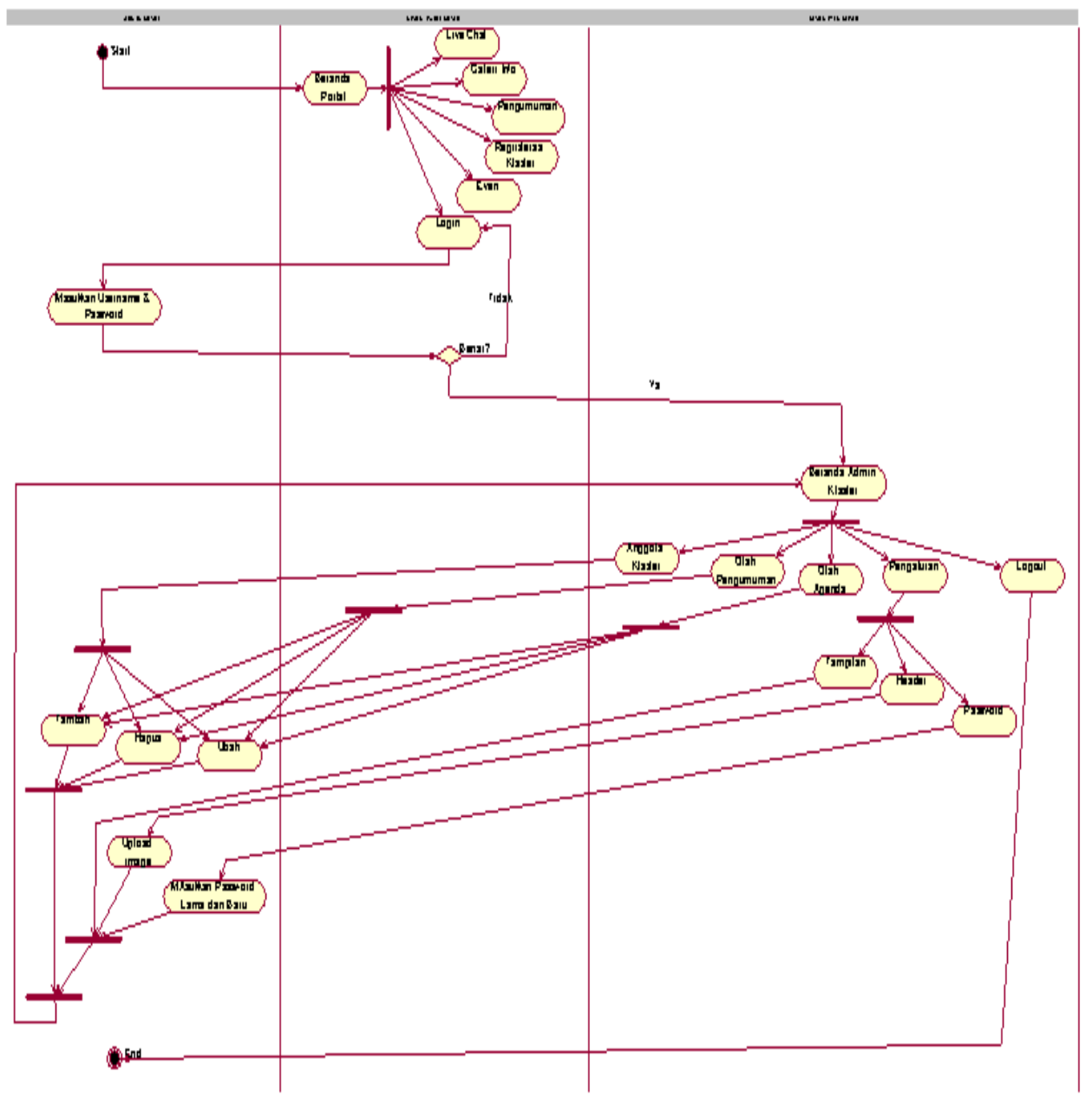

Gambar 8 Activity Diagram Admin Klaster[12]

Activity diagram menggambarkan proses-proses yang terjadi dari suatu aktivitas dimulai sampai berhenti.

Gambar 8 menggambarkan aktivitas-aktivitas yang bisa dilakukan oleh admin klaster. Aktivitas-aktivitas tersebut diantaranya adalah manage anggota klaster, manage agenda, manage pengumuman dan manage pengaturan (tampilan, header, password). Sebelum mengakses menu-menu tersebut harus melakukan login terlebih dahulu. 


\section{Sequence Diagram}

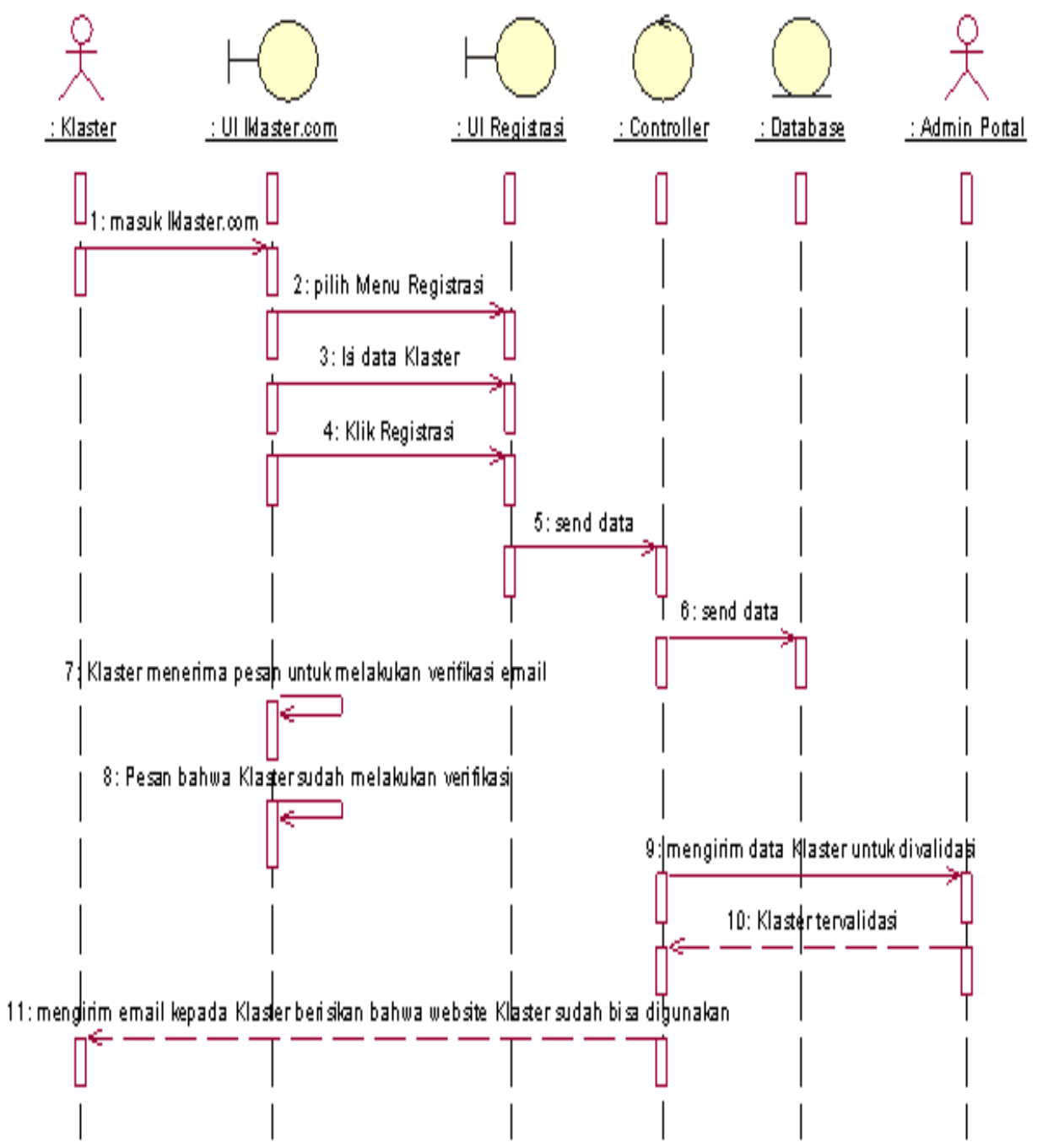

\section{Gambar 9 Sequence Diagram Registrasi[12]}

Sequence diagram menggambarkan interaksi antar obyek di dalam dan di sekitar sistem (termasuk pengguna, display, dan sebagainya) berupa message yang digambarkan terhadap waktu. Gambar 9 merupakan sequence diagram untuk aktivitas sebagai Guest yang melakukan registrasi menjadi admin klaster. 


\section{Class Diagram}

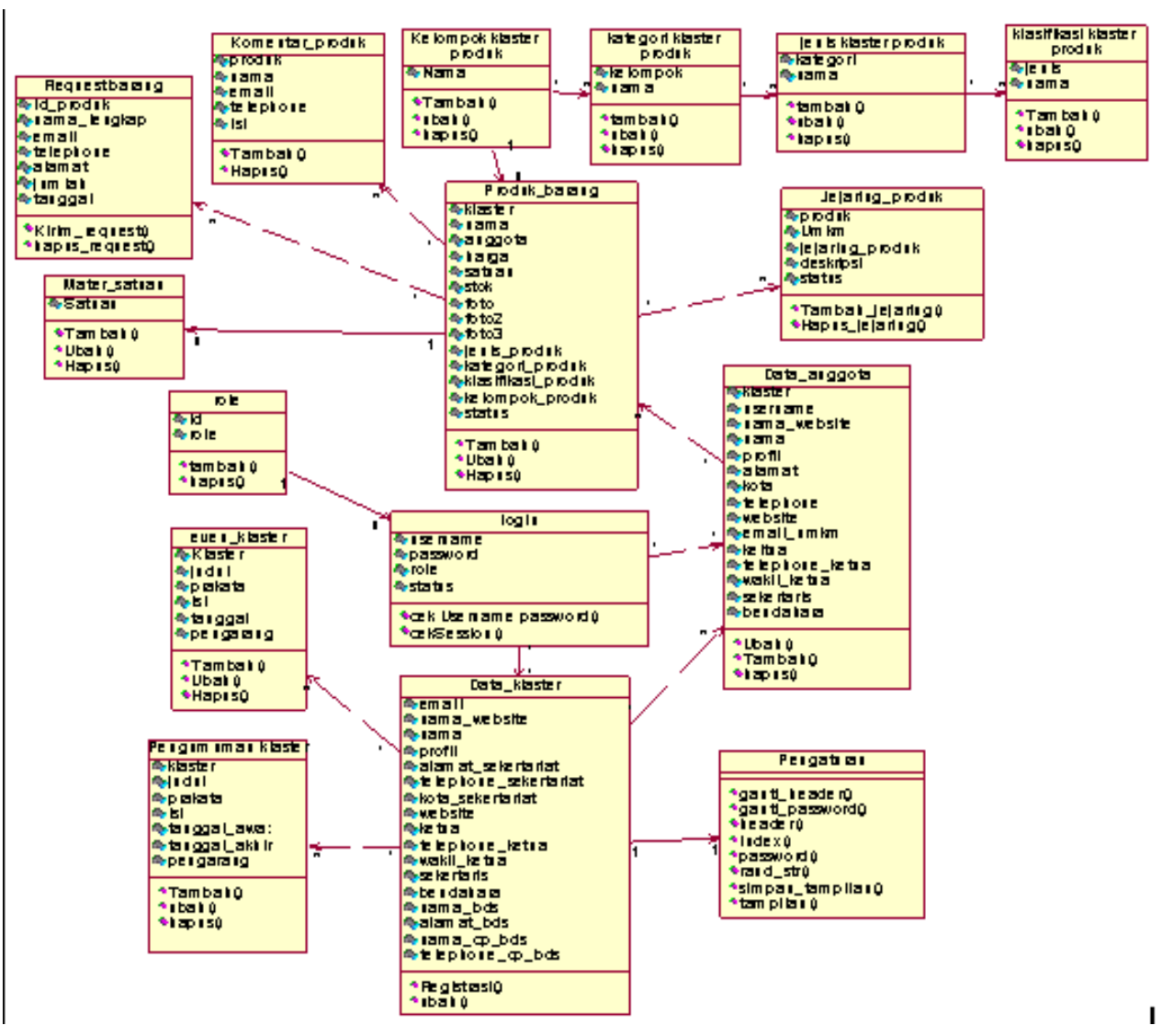

\section{Gambar 10 Class Diagram System[12]}

Class diagram system pada Gambar 10 merupakan perancangan class yang akan dibuat pada aplikasi tersebut yang terdapat pada Controller dan Model, meliputi : class role, class login, class data_klaster, class pengumuman_klaster, class even_klaster, class pengaturan, class data_anggota, class jejaring_produk, class produk_barang, class master_satuan, class request_barang, class komentar_produk,class kategori_klaster_produk, class kelompok_klaster_produk, class jenis_klaster_produk, class klasifikasi_klaster_produk.

\section{Perancangan User Interface}

Dalam perancangan sistem informasi Sistem Jejaring Klaster diperlukan user interface dalam penggunaannya. Perancangan user interface dilakukan untuk mendasari pembuatan tampilan aplikasi yang akan dibuat. Gambar 11 merupakan rancangan user interface Menu 
Utama pada Sistem Jejaring Klaster. Sistem yang dibangun berbasis web, dengan header, sebuah sub menu dan isi web di dalamnya.

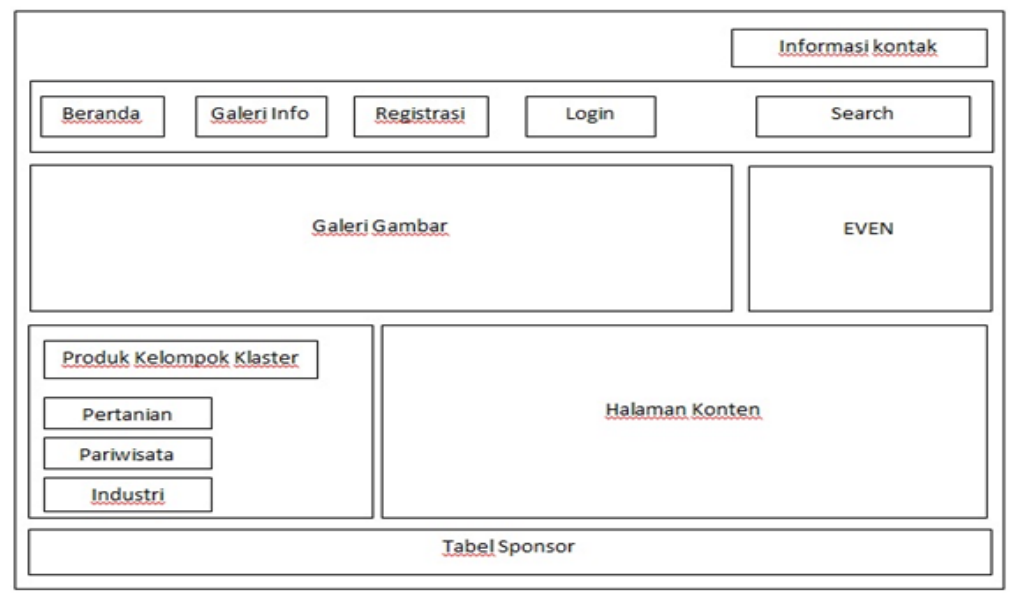

Gambar 11 User Interface Menu Utama[12]

\section{HASIL DAN PEMBAHASAN}

Setelah melakukan tahap perancangan, langkah selanjutnya adalah mengimplementasikannya. Pada tahap implementasi dihasilkan sebuah aplikasi yaitu Sistem Jejaring Klaster berbasis Web dan telah di-hosting dengan nama domain iklaster.com. iklaster.com dibuat melalui beberapa tahap perancangan prototype, dan tahap perancangan prototype dapat dilihat pada Dokumentasi Prototyping.

\section{Dokumentasi Prototyping}

Prototype I : Uji dan Evaluasi Sistem: 23 Feb 2012 di Kab. Demak

Pada prototype I pada web portal telah terdapat penggolongan produk, verifikasi email saat regristerasi klaster, lihat jejaring. Dan kekurangan pada prototype I di web portal adalah belum adanya validasi Regristerasi Klaster oleh Admin Portal, agenda dan pengumuman, pemesanan produk oleh Guest, komentar produk oleh Guest. Pada prototype I website admin Klaster telah terdapat menu Pengaturan : header, tampilan dan password, pengelolaan anggota Klaster. Dan kekurangan pada prototype I di website Klaster adalah belum adanya belum ada nama website Klaster yang diinginkan pada saat peroses regristerasi, website Klaster belum memiliki alamat URL sendiri, belum terdapat agenda dan pengumuman. Pada prototype I ditemukan khususnya di telah terdapat add jejaring dan lihat jejaring. Dan kekurangan pada prototype I di website anggota adalah belum adanya detil produk, lihat daftar pemesanan, notifikasi terima dan tolak jejaring, image produk atau UMKM/Klaster pada lihat jejaring.

Prototype II: Uji dan Evaluasi Sistem: 24 April 2012 : di Bapeda Wonosobo, 26 April 2012 : di Bapeda Pemalang. 
Beranda portal sudah memiliki Header yang berbeda bertuliskan iKl@s. Pada prototype II di web portal telah terdapat Penggolongan Produk Verifikasi Email saat regristerasi klaster Agenda, Pengumuman Lihat JejaringPemesanan/Request Produk oleh Guest dengan Login, adanya penambahan Even. Dan kekurangan pada prototype II di web portal adalah belum adanya Validasi Regristerasi Klaster oleh Admin Portal Komentar Produk oleh Guest. Terdapat validasi Klaster oleh Admin Portal pada prototype ini, setelah diterima dalam proses validasi maka Klaster akan memiliki halaman web-nya, jika ditolak maka data klaster akan dihapus. Pada prototype II ditemukan khususnya di website Admin Klaster belum ada perubahan dari prototype I. Pada prototype II ditemukan khususnya di telah terdapat deskripsi detil produk dan stoknya. Dan kekurangan pada prototype I di website Anggota belum disempurnakan pada prototype II ini.

\section{Prototype III: 11 May 2012}

Pada Gambar prototype III, beranda portal sudah memiliki Header yang berbeda bertuliskan iKlaster.com. Pada prototype III ditemukan perubahan pada web portal telah terdapat penambahan Contact Information dan website ini sudah memiliki Domain dan sudah di Hosting. Pada prototype III ditemukan perubahan pada website Admin Klaster belum ada perubahan dari prototype I. Pada prototype III ditemukan perubahan pada Website Anggota belum ada perubahan dari prototype II.

\section{Prototype IV: 3 Juni 2012}

Pada prototype III ditemukan perubahan pada web portal yaitu sudah ada jumlah Produk pada Kelompok Klaster Homepage Portal, Sudah ditambahkan Verifikasi Regristerasi Klaster. Pada prototype IV ditemukan perubahan pada website Admin Klaster yaitu sudah memiliki URL Website berdasarkan Regristerasi Klaster dengan format iklaster.com/klaster/ nama_website, sebagai contoh http://iklaster.com/klaster/tani_mahardika. Pada prototype IV ditemukan perubahan pada di Website Anggota yaitu dengan adanya Pemesanan/Request Produk oleh Guest sudah ada tanpa Login, Lihat Daftar Pemesanan, Image produk atau UMKM/ Klaster pada Lihat Jejaring, Notifikasi: Terima atau Tolak Jejaring, Fasilitas Komentar Produk oleh Guest.

\section{Prototype V: 6 Juli 2012}

Perubahan yang terjadi pada Homepage Portal yaitu terjadi perubahan pada beranda portal tentang adanya informasi jumlah antrian Regristerasi Klaster dibawah menu Kelompok Produk Klaster. Perubahan yang terjadi pada Admin Portal yaitu disediakannya fasilitas hapus Regristerasi Klaster jika melakukan Aktivasi > 3 (lebih dari) hari pada email verifikasi yang dikirim oleh Admin Portal. Dari hasil evaluasi prototype V, pengguna menyatakan bahwa prototype $\mathrm{V}$ telah cukup memenuhi kebutuhan. Dengan demikian, proses berhenti karena tahapan dalam metode prototyping dinyatakan selesai jika pengguna menyatakan bahwa prototype yang dibangun sudah memenuhi kebutuhan pengguna.

\section{Hasil Implementasi}

Implementasi Model View Controller (MVC)

Penerapan konsep MVC pada sistem yang dibuat terlihat pada Gambar 12. 


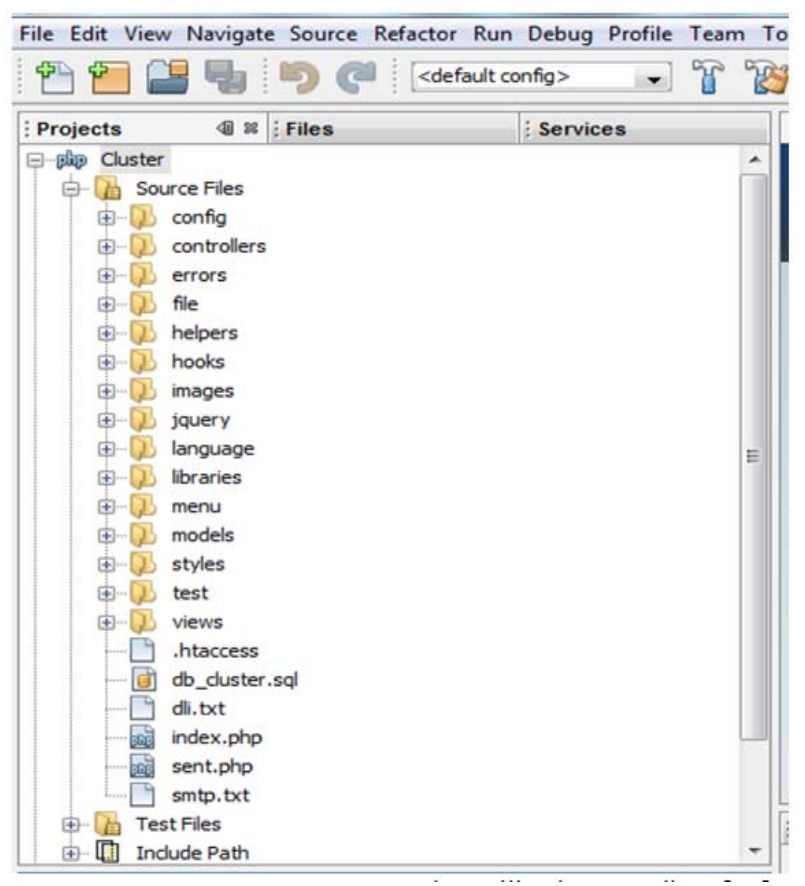

Gambar 12 Penerepan MVC Pada Aplikasi yang Dibuat[12]

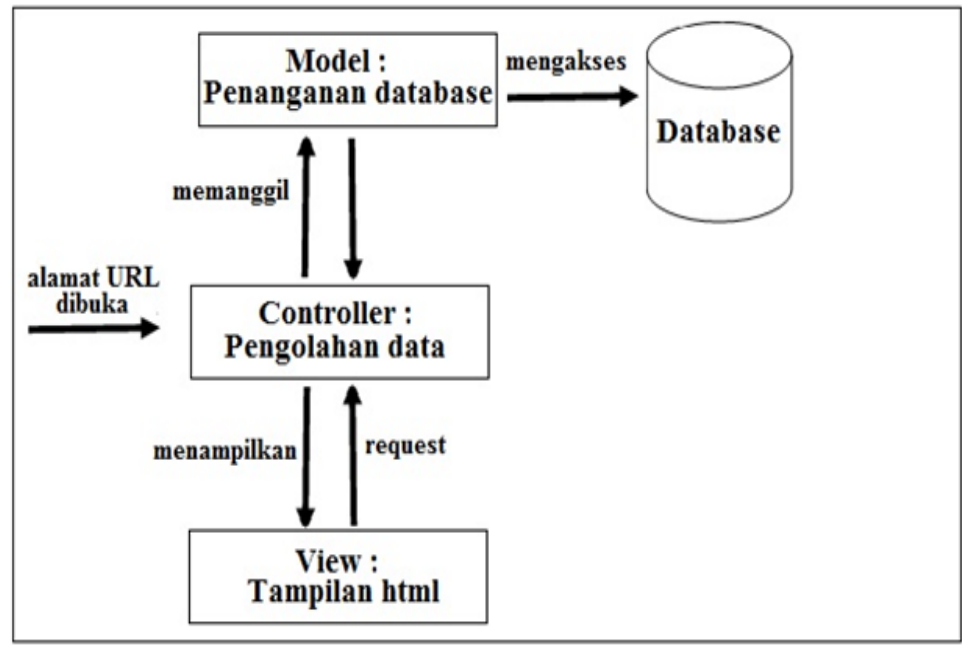

Gambar 13 Cara Kerja MVC Pada Aplikasi yang Dibuat 
Mekanisme kinerja MVC pada aplikasi yang dibuat, terlilhat pada Gambar 13 yaitu ketika suatu alamat URL dibuka maka mengakses controller (yang ada dalam folder controllers) untuk menjalankan fungsi. Penerapan skema arsitektur MVC pada aplikasi dapat dijelaskan dengan contoh yaitu pada saat proses registrasi. Pertama, user masuk ke halaman registrasi yang berada pada halaman depan iklaster.com. Pada saat melakukan klik pada registrasi akan dipanggil controller registrasi.php dan controller registrasi.php memanggil view registrasi.php. Setelah user mengisi data dan klik submit, pada controller dilakukan pengecekan username dan nama website apakah sudah digunakan apa belum, jika belum maka controller akan masuk ke bagian model. Pada bagian model data yang tadi telah di-input-kan akan disimpan pada database. Setelah menyimpan lalu kembali lagi ke controller. Controller akan mengirim e-mail, setelah mengirim e-mail maka controller akan melakukan load view yang berisi silahkan cek e-mail saudara. Setelah user membuka email, akan ada link yang setelah diklik masuk ke bagian controller. Pada bagian controller akan diambil username dan dicocokan validasinya pada bagian model, jika cocok maka controller load halaman view yang berisi bahwa registrasi anda berhasil. Setelah itu tunggu validasi dari admin portal.

Tampilan halaman muka iklaster.com dapat dilihat pada Gambar 14.

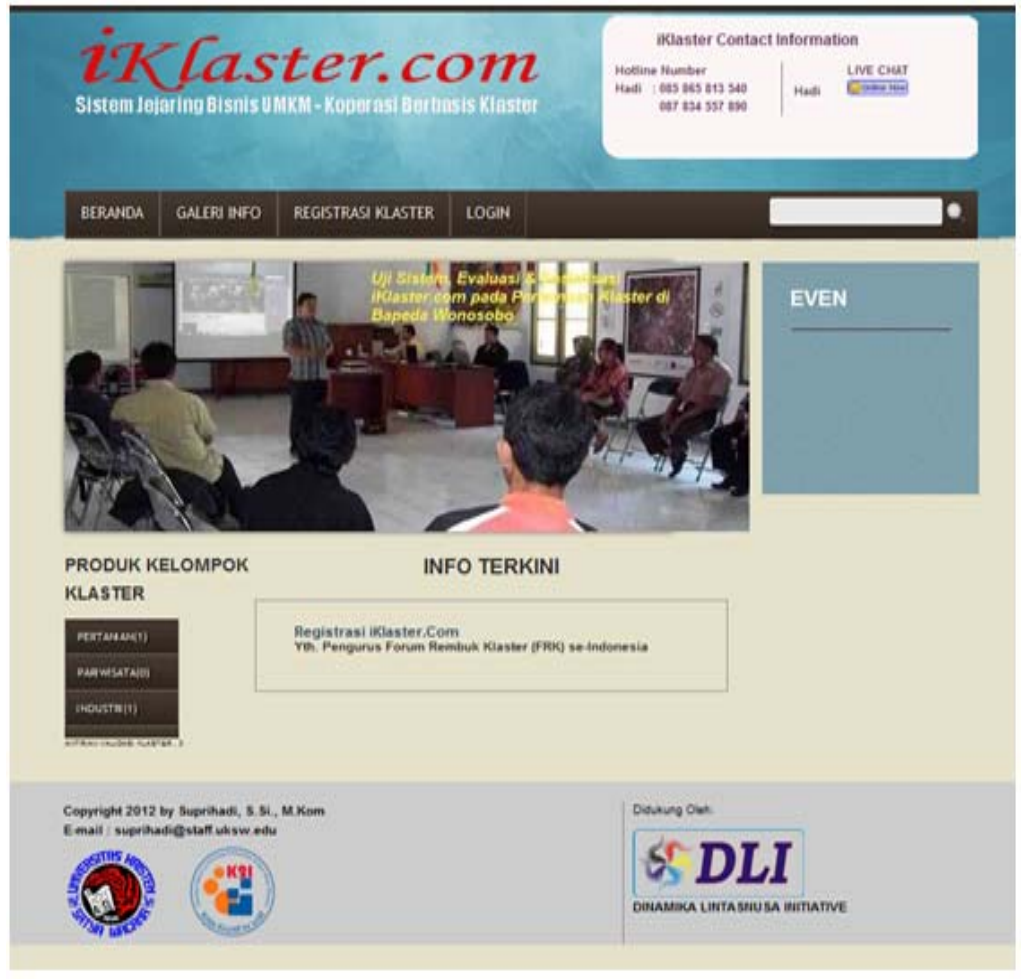

Gambar 14 Tampilan Halaman Utama iklaster.com 
Aplikasi yang dibangun berbasis web dan dibuat menggunakan Framework Codeigniter. Framework Codeigniter adalah framework yang berbasis Model View Conttroller yang memisahkan aplikasi logika dengan presentasi pada halaman web.

Model berisikian bagian-bagian yang mengelola data dengan sistem query database, mengambil dan menyimpan data, menghapus data, mengurutkan data, mencari data dan proses lainnya yang berhubungan dengan pengelolaan data. Bertugas untuk mengelola berbagai model yang diperlukan oleh aplikasi. Seperti yang terlihat pada Tabel 8 [12].

\begin{tabular}{|c|c|c|}
\hline No & Class & Keterangan \\
\hline 1. & model cluster.phpp & Query-oulery untuk mengambil data klaster" \\
\hline 2. & mod infophip & Queity-query untuk mengambil data info \\
\hline 3. & mod jejaring php & Querv-oulery untuk mengambil data jejaring \\
\hline 4. & mod komentar,php & Query-oulery untuk mengambil data komentar \\
\hline 5. & mod login,php & Query-query untuk mengambil data login \\
\hline 6. & mod produk.php & Query-query untuk mengambil data produlk \\
\hline 7. & mod satuan.phip & Query-query untuk mengambil data nilai satuan \\
\hline
\end{tabular}

View bertugas mengelola tampilan aplikasi, sesuai dengan namanya, merupakan bagian yang dapat dilihat dan dikelola oleh user. Bagian ini umumnya terdiri dari tombol-tombol, tabs, check list, combo box, teks, audio, button, list, table dan lain-lain. Implementasi yang dilakukan pada bagian View dikelompokkan dalam package-package untuk lebih memudahkan dalam pengembangan, yaitu dapat dilihat pada Gambar 15. 


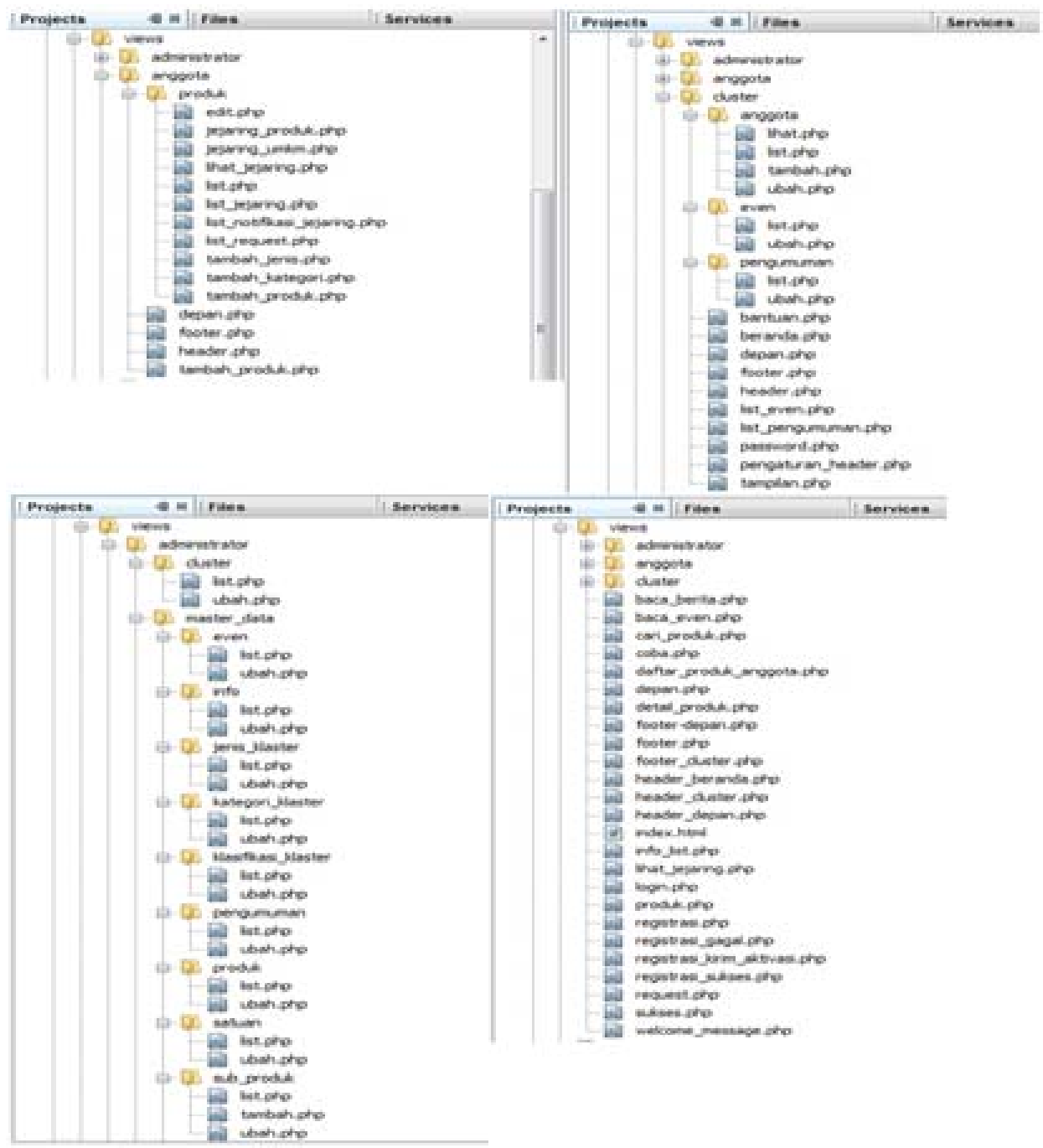

\section{Gambar 15 Folder View[12]}

Controller bertugas untuk menghubungkan antara bagian model dan bagian view. Bagian ini umumnya menangani request yang disampaikan saat user melalui bagian view untuk mencari padanan model yang sesuai dengan request tersebut. Controller juga bertugas untuk menyampaikan hasil request kembali kepada user melalui bagian view, misalnya dalam bentuk list, teks, table, atau grafik. Tabel 10. merupakan tabel controller [12]. 


\begin{tabular}{|c|c|c|}
\hline No. & Class & Keterangan \\
\hline 1. & Baca.php & Untuk memuat agenda, even, pengumuman pengumumankla ster tertentu \\
\hline 2. & Depan.php & Untuk memuat halaman beranda \\
\hline 3. & Klaster.php & Untuk memuat nama website klaster pada URL \\
\hline 4. & Lihat.php & $\begin{array}{l}\text { Untuk memuat lihat detail produk, jej aring umkm danproduk, jenis } \\
\text { produk, kategori produk, kirm komentar, kirim re quest, kla sifikasi, lihat } \\
\text { produk, request produk }\end{array}$ \\
\hline 5. & Login.php & Untuk proses login \\
\hline 6. & $\begin{array}{l}\text { Registrasi.php } \\
\text { Folder: Administrator }\end{array}$ & Untuk proses registrasi \\
\hline 7. & Cluster.php & Untuk mengatur klaster, bisa menambah dan menghapus kla ster \\
\hline 8 . & Depan.php & Untuk beranda depan admin portal \\
\hline 9. & Even.php & Untuk mengelola even portal \\
\hline 10. & info.php & Untuk mengelola info portal \\
\hline 11. & jenis_cluster.php & Untuk menambah ubah hapus jeris kla ster \\
\hline 12. & kategori_cluster.php & Untuk menambah ubah hapus kategoriklaster \\
\hline 13. & kla sifikasi_cluster.phy & Untuk menambah ubah hapus klasifikasi kla ster \\
\hline 14. & logout.php & Untuk proses logout \\
\hline 15 . & pengumuman.php & Untuk mengelola pengumumanportal \\
\hline 16. & $\begin{array}{l}\text { satuan.php } \\
\text { folder: anggota }\end{array}$ & Untuk mengelola satuanproduk \\
\hline 17. & depan.php & Untuk beranda depan anggota \\
\hline 18. & logout.php & Untuk proses logout \\
\hline 19. & $\begin{array}{l}\text { produk:php } \\
\text { folder: cluster }\end{array}$ & Untuk pengolahan data pro duk \\
\hline 20. & anggota.php & Untuk mengelola anggota \\
\hline 21. & bantuan phy & Untuk load view b antuan.php \\
\hline 22. & depan.php & Untuk halaman beranda a dmin kla ster \\
\hline 23. & logout.php & Untuk proses logout \\
\hline 24 . & pengaturan.php & Untuk ubahpassword hea der dan tampilan \\
\hline
\end{tabular}

\section{Tabel 10. Tabel Controler}

\section{Implementasi multiweb pada satu domain}

Proses pembuatan website bagi klaster pada aplikasi iklaster.com dilakukan pada saat regristerasi klaster. Proses registrasi diatur dalam Class registrasi.php pada folder Controller dan kode program tersebut dapat dilihat pada Kode Program 1 sebagai berikut: Kode Program 1 Perintah Controller pada class registrasi.php

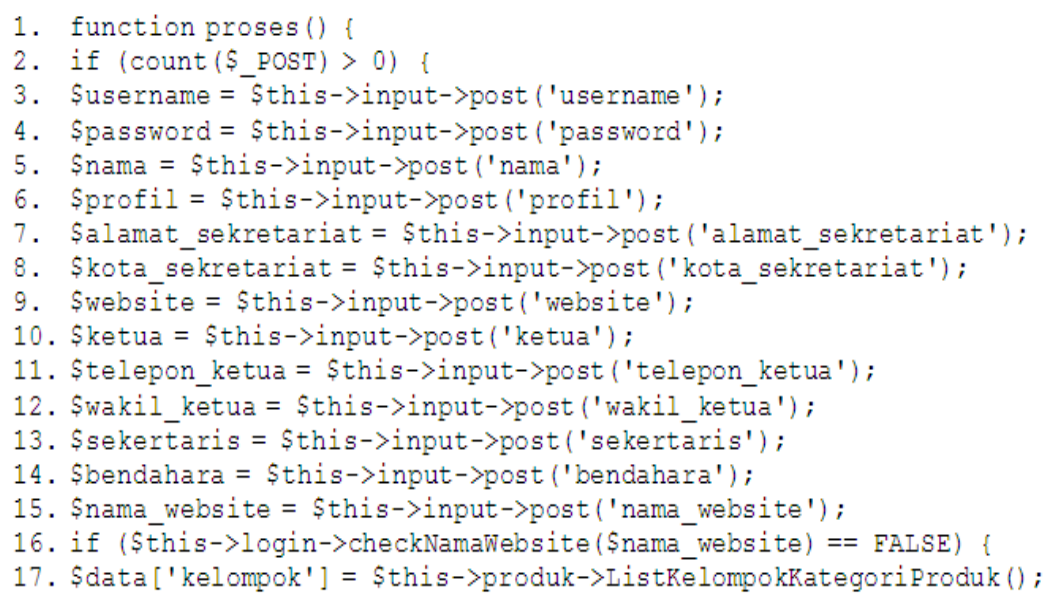




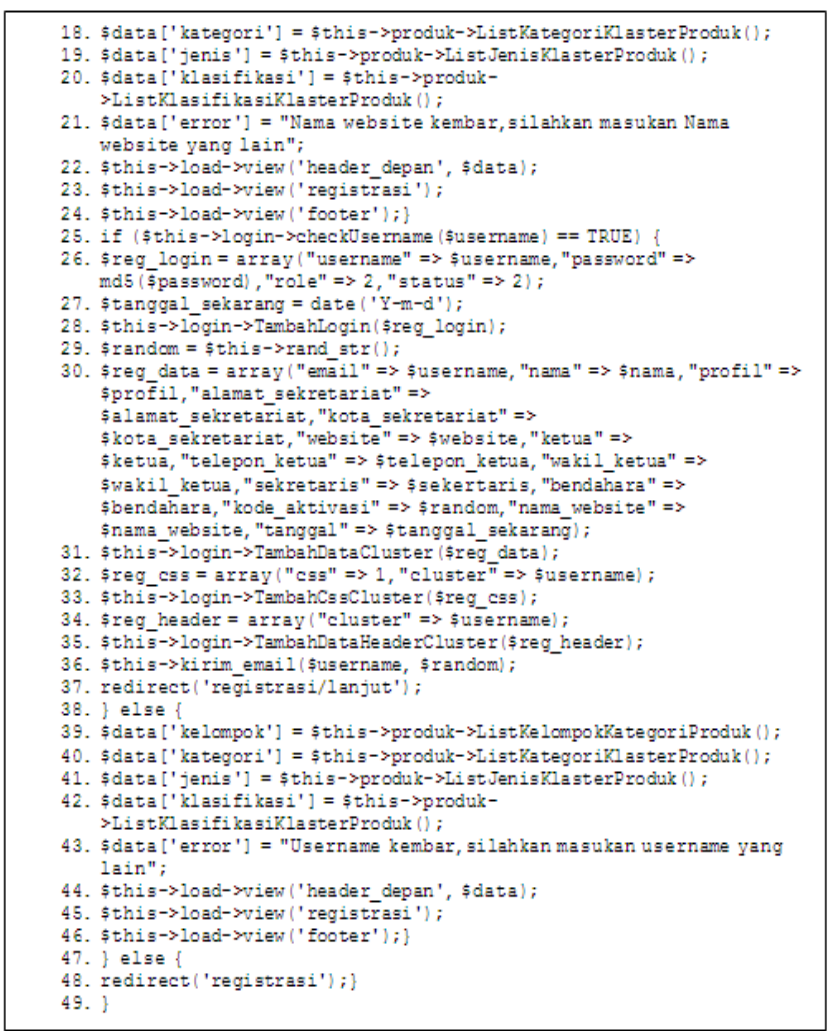

Penjelasan Kode Program 1 sebagai berikut:

Baris 1 nama fungsi

Baris 2 mengecek apakah ada inputan dari user

Baris 3-15 mengambil inputan dari user

Baris 16-24 mengecek apakah nama website dari user masih tersedia

Baris 25 mengecek username masih tersedia atau tidak

Baris 26 membuat variable bertipe array dengan isi username,password yang dienkripsi md5, role $=2$ (sebagai klaster), status $=2$ (belum mengirim verifikasi)

Baris 27 mengambil tanggal dari sistem

Baris 28 menambahkan data dari baris 26 ke dalam tbl_login

Baris 29 membuat variable ramdom dengan isi karakter acak 32 karakter

Baris 30 membuat variable bertipe array yang berisikan data registrasi user

Baris 31 menambah data dari baris 30 kedalam tbl_data_cluster

Baris 32 membuat variable bertipe array yang berisikan data css default klaster

Baris 33 menambah data dari baris 32 kedalam tbl_css_cluster

Baris 35 menambah data yang berisi username pendaftar kedalam tbl_header_cluster

Baris 36 memanggil fungsi kirim e-mail dengan memasang e-mail dan kode aktivasi.

Baris 38-46 jika username sudah ada, tampilkan error dan inputan yang diisikan. 


\section{UJISISTEM}

\section{Uji Validitas Sistem}

Untuk pengujian aplikasi jejaring klaster dilakukan dengan metode uji validitas. Pengujian dilakukan oleh developer seperti tercantum pada Tabel 11 sebagai berikut :

a. Pengujian registrasi yaitu untuk mengecek apakah fungsional dari form registrasi telah berjalan dengan baik. Dari pengujian yang dilakukan didapatkan kesimpulan bahwa form registrasi telah berfungsi dengan baik.

Tabel 11. Pengujian Validitas Untuk Form Registrasi

\begin{tabular}{ccllc}
\hline No & Aktivitas dan Event & \multicolumn{1}{c}{ Input } & \multicolumn{1}{c}{ Output } & Status Pengujian \\
\hline 1. & $\begin{array}{l}\text { Registrasi klaster dan } \\
\text { klik tombol Registrasi } \\
\text { pada menu utama }\end{array}$ & Klaster & $\begin{array}{l}\text { Jika masin terdapat field belum diisi lengkap, } \\
\text { maka muncul alert: Terdapat field inputan } \\
\text { yangkosong harus diisi }\end{array}$ & Valid \\
\hline 2. & Penamaan website & Penamaan & a. Nama website yang dimasukkan sudah & Valid \\
& & Website & terdaftar sebelumnya akan ada & \\
& & pemberitahuan & \\
& & b. Dalam memberikan nama website tidak & \\
& & sesuai ketentuan tidak akan diijinkan & \\
\hline
\end{tabular}

b. Pengujian untuk menu-menu yang dapat diakses admin klaster meliputi form tambah anggota dan form pengaturan yang berfungsi untuk merubah header, password dan tampilan. Dari pengujian yang dilakukan didapatkan kesimpulan bahwa form tambah anggota dan form pengaturan telah berfungsi dengan baik.

Tabel 12. Pengujian Validitas Pengaturan dan Add Anggota

\begin{tabular}{|c|c|c|c|c|}
\hline No & Aktivitas dan Event & Input & Output & Status Pengujian \\
\hline 1. & Tambah anggota & Data anggota klaster & $\begin{array}{l}\text { Jika masih terdapat field belum } \\
\text { diisi lengkap, maka muncul alert } \\
\text { : Terdapat field inputan yang } \\
\text { kosong harus diisi }\end{array}$ & Valid \\
\hline 2. & Ubah header & Gambar & $\begin{array}{l}\text { Tampilan header berubah,jika } \\
\text { tidak mengisikan inputan maka } \\
\text { tampilan header akan kosong }\end{array}$ & Valid \\
\hline 3. & Ubah password & $\begin{array}{l}\text { Memasukan password } \\
\text { lama dan dua kali } \\
\text { password baru }\end{array}$ & $\begin{array}{l}\text { a. Jika password lama salah } \\
\text { maka muncul peringatan } \\
\text { password salah } \\
\text { b. Jika password lama salah } \\
\text { maka muncul peringatan } \\
\text { password salah }\end{array}$ & Valid \\
\hline 4. & Ubah tampilan & Memilih warna & Warna tampilan berubah & Valid \\
\hline
\end{tabular}




\section{Uji Responden}

Uji sistem ini didasarkan pada pengujian yang dilakukan oleh 25 (duapuluh lima) responden dari beberapa klaster di Kabupaten Pemalang, Wonosobo dan Demak yang merupakan para pengurus dan anggota klaster. Setelah uji sistem, para responden mengisi kuesioner yang berisi pertanyaan seputar penggunaan aplikasi Sistem Jejaring Klaster berbasis Web, yaitu sebagai admin portal website klaster dan admin website klaster.

Berdasarkan hasil uji sistem pada admin portal website klaster, diperoleh hasil bahwa sebanyak 26\% responden menyatakan bahwa sistem sangat mudah digunakan dan 61\% responden menyatakan bahwa sistem mudah digunakan, sementara sisanya menyatakan sangat sulit, sulit dan tidak tahu.

Sedangkan untuk uji sistem admin website klaster didapatkan hasil sebanyak 24\% responden menyatakan bahwa sistem sangat mudah digunakan dan 66\% responden menyatakan bahwa sistem mudah digunakan, sementara sisanya menyatakan sangat sulit, sulit dan tidak tahu.

\section{SIMPULAN}

Berdasarkan hasil perancangan dan implementasi Sistem Jejaring Klaster Berbasis Web Menggunakan Metode Model View Controller, maka dapat diperoleh kesimpulan yaitu :

- Desain multi website dengan memanfaatkan satu domain dengan cara setiap page didalam website memiliki kerangka tampilan yang sama sangat tepat guna memfasilitasi berbagai kelompok klaster. Setiap website klaster memiliki situs dengan format URL: iklaster.com/klaster/nama_website berdasarkan nama_website yang dimasukkan pada saat proses registrasi klaster.

- $\quad$ Berdasarkan mapping produk klaster dapat diperoleh desain atribut produk dan atribut klaster, yaitu dikelompokkan kedalam 4 (empat) golongan yang sama antara lain Kelompok, Kategori, Jenis dan Klasifikasi. Atribut produk dan atribut klaster tersebut dipergunakan sebagai dasar penerapan konsep jejaring sosial pada aplikasi e-commerce Sistem Jejaring Klaster. Struktur data yang sama sangatlah tepat jika menggunakan framework dengan metode MVC karena lebih efisien dalam proses implementasi web klaster ini.

- $\quad$ Sedangkan data klaster dan produk anggota klaster yang terdapat didalamnya dikelola oleh class-class model. Manajemen prosesnya dikelola oleh class-class controller. Pada database, informasi klaster disimpan dalam tabel data_cluster, tampilan website klaster pada tabel css_cluster dan tampilan header klaster disimpan dalam tabel header_cluster. Tampilan pada setiap page dikelola oleh class-class pada folder view.

- Penggunaan framework CodeIgniter membantu memudahkan dalam implementasi aplikasi karena framework CodeIgniter mendukung arsitektur Model View Controller (MVC) yang memisahkan antara model, view dan controller.

\section{DAFTAR PUSTAKA}

[1] Bank Indonesia, 2007, Pilot Project Pengembangan Klaster Mebel Rotan Di Trangsan Kec. Gatak Kab. Sukoharjo Jawa Tengah, http://www.bi.go.id/NR/rdonlyres/ 7D54C99C-C1E2-40E4-A428-309F234546DE/10372/Boks3.pdf, Diakses tanggal: 8 April 2012 
[2] FPESD Jateng, 2010, Rakor FPESD Jawa Tengah, http://www.fpesd.org/?Home, Dikases tanggal: 8 April 2012

[3] Saputra, Irwan, 2011, Multimedia Pembelajaran Bahasa Inggris Menggunakan Konsep Jejaring Sosial Berbasis Web, http://dir.unikom.ac.id/s1-final-project/fakultas-teknikdan-ilmu-komputer/teknik-informatika/2011/jbptunikompp-gdl-irwansaput-26098/11.uniko-r.pdf/pdf/1-1.uniko-r.pdf. Diakses tanggal: 4 Juni 2012

[4] Wijaya,I Wayan Gede Suma, Eko Heri Susanto, M.Kom, 2012, Membangun Website eCommerce dengan Teknik MVC Menggunakan Framework CodeIgniter, http:// www.general-files.com/download/gs56068415h17i0/Jurnal_Jikom__ $\mathrm{M}$ e m b a n u n dengan_Teknik_MVC_Menggunakan_Framework_CodeIgniter.pdf.html. Diakses tanggal: 6 Juni 2012

[5] Jogiyanto, 2003, Pengertian Sistem Informasi, Jogjakarta : Skripta Media.

[6] Porter, M.E., 1998, On Competition. Boston: Havard Business School Publishing.

[7] Ridwan, Muhammad, Jejaring Sosial (Social Networking), http:// www.ridwanforge.net/blog/jejaringsosial-social-networking, Diakses tanggal: 28 Juni 2012

[8] Upton, David. 2007. CodeIgniter for Rapid PHP Application Development Improve your PHP coding productivity with the free compact open-source MVC CodeIgniter framework. Birmingham : Packt Publishing Ltd.

[9] User_guide, http://Codeigniter.com, Diakses tanggal: 3 januari 2012

[10] eNode Inc, 2002, Arsitektur Model, View, Controller. Yogyakarta : Skripta Media.

[11] Pressman, 2001, Software Enginering: A Practicioner's Approach $5^{\text {th }}$ Edition, America : Mc. Graw Hill.

[12] Suprihadi, dkk, 2012, Rancang Bangun Sistem JeJaring Klaster Berbasis Web Dengan Pedekatan Model E-Commerce Marketplace, Salatiga: FTI-UKSW 